in raising soil fertility to the high level required for vegetable production shows that farmyard manure exerts the greatest single effect. For some crops, however, the greatest yield is only obtained by supplementing with fertilizer. More detailed chemical investigations showed that there was an accumulation of sucrose, fructose and glucose, and a decrease in phosphorylated intermediaries, in the roots of beet immediately before flowering.

The report describes many studies on competition between weeds and crop, and the effects of preplanting treatments. Various agents for weed control are under investigation, but it is interesting to note that the mere fact of growing vegetables for three years has reduced the number of weed seeds in the soil to about one-sixth the original number. Studies on the control of environmental conditions include extensive work on irrigation, and lettuce particularly benefited from adequate watering through its period of growth. Disease studies are now extensive, but perhaps the most significant findings are that silvering disease of beet can be controlled by seed treatment with streptomycin, the effectiveness of aldrin in reducing club-root disease, and the use of zinc frit for the control of powdery mildew of turnips and cabbage. Entomological investigations are concerned mainly with cabbage root fly, carrot fly and the root aphid of lettuce, while in methods of control, seed treatment and soil incorporation figure largely. Plant breeding is perhaps slow to give immediate results, but the report shows useful progress with many vegetables; in this, as indeed in other sections, reference must be made to the report itself, and it is clear that as the years go by it will become more and more valuable.

\section{Plasma Physics and Thermonuclear Research}

THE new section, Part $C$, of the Journal of Nuclear Energy is to be published quarterly and is devoted to plasma physics, accelerators and thermonuclear research (Pergamon Press, 4-5 Fitzroy Square, London, W.1). As Sir George Thomson explains in his brief foreword to the first issue (1, Nos. 1/2, October 1959), plasma physics is part of that study of gaseous discharges to which physics owes the fundamental discoveries of electrons and of isotopes, and from which it is hoped to be able to solve the problem of obtaining controlled energy from fusion reactions between nuclei of isotopes of hydrogen. Prof. M. S. Livingston in his foreword explains that accelerator technology has contributed significantly to the newer technology of thermonuclear science, and therefore the new journal will perform an important and useful function in sponsoring the merger of the two technologies with the study of plasma physics. In addition to eight original contributions, the October issue contains abstracts in English, prepared by the U.S. Atomic Energy Commission, of articles from "The Physics of Plasmas", published by the U.S.S.R. Academy of Sciences, a collection divided into four volumes in which are described the theoretical and experimental investigations carried out during 1951-58 in the Institute of Atomic Energy of the U.S.S.R. Academy on controlled thermonuclear reaction and associated sub. jects. Other features of the issue are translations of articles from Atomnaya Energiya and a list of titles of current papers and reports on plasma physics, accelerators and thermonuclear research appearing in some 50-100 journals published throughout the world. The October list covers publications since
January 1, 1959. The editor-in-chief of Part $C$ is Dr. J. V. Dunworth.

\section{Russian Chemical Journals}

The Chemical Society announces that cover-tocover translations of two additional Russian chemical journals are to be published with the assistance of the Department of Scientific and Industrial Research. The Russian Journal of Physical Chemistry (Zhurnal Fizicheskoi Khimii) is being published by the Society in translation starting with the issue for July 1959. It is intended that subsequent monthly issues will appear regularly, and it is hoped that the interval between the receipt of the Russian original and the publication of the translation will eventually be reduced to about three months. Mr. R. P. Bell is scientific editor of the translation. Another journal, Uspelchi Khimii, will be published monthly in translation under the title Russian Chemical Reviews, starting with the issue for January 1960, which it is hoped to make available in April. The scientific editor of the translation will be Dr. J. N. Agar, assisted by Dr. A. R. Katritzky and Dr. R. H. Prince. Translations for these journals are supplied for the Society by Infosearch, Ltd., and distribution is undertaken by the Cleaver-Hume Press, Ltd. Subscription inquiries should be addressed to the sole distributors, Cleaver-Hume Press, Ltd., 31 Wright's Lane, London, W.8.

\section{The United States National Museum}

IN a comprehensive report for 1959 it is stated that the site near the Washington Monument is now being prepared for the proposed Museum of History and Technology (The United States National Museum. Annual Report for the year ended June 30, 1959. Pp. vi + 178. Washington, D.C.: Government Printing Office, 1959). The policy of this Museum is described as "to illustrate by means of the historic collections in the Smithsonian the cultural and technological development of the Nation since Colonial times". The plans include some thirty-eight major halls which have been coherently related to show a logical sequence of events. The needs of the individual museum visitor have been kept in mind, for it is conservatively estimated that some five million persons will enter the building each year. Provision is made for adequate air conditioning for the protection of objects as well as the comfort of visitors, circuits for television and electronic guide devices, and other electrical and plumbing devices in this great modern display unit. The plans thus indicate a museum building that will for the first time allow the great collections of the Smithsonian to be viewed in an adequate manner. During the sixth year of the continuing modernization programme work has also moved steadily forward on the other two fronts, namely, the renovation of the permanent exhibition halls in existing buildings and assistance to other branches of the Smithsonian Institution in the planning and presentation of exhibits.

\section{Proteins from Grass}

PIRIE and other scientific workers have directed attention to reserves of protein available in grass and other chlorophyll-containing material normally consumed as animal foodstuffs, but potentially of use to man. The efficient production of good-quality edible protein from such sources depends on the solution of various biochemical engineering problems which have been investigated by the Rothamsted 